\title{
Massive hard coral loss after a severe bleaching event in 2010 at Los Roques, Venezuela
}

\author{
Carolina Bastidas $^{1,3}$, David Bone ${ }^{1,3}$, Aldo Croquer $^{2,3}$, Denise Debrot $^{3}$, Elia Garcia ${ }^{1,3}$, Adriana \\ Humanes ${ }^{3}$, Ruth Ramos ${ }^{3}$, Sebastian Rodríguez ${ }^{3}$ \\ 1. Dept. Biología de Organismos, Universidad Simón Bolívar. Caracas 1080 Venezuela \\ 2. Dept. Estudios Ambientales, Universidad Simón Bolívar. Caracas 1080 Venezuela \\ 3. Centro de Estudios Ecotoxicológicos en Ambientes Marinos CETOXMAR- Universidad Simón Bolívar. Caracas 1080 \\ Venezuela \\ Email of all authors: cbastidas@usb.ve; dbone@usb.ve; acroquer@usb.ve; ddebrot@gmail.com; emgarcia@usb.ve; \\ adrihumanes@gmail.com, ruthr@usb.ve; sebastianr@usb.ve \\ Corresponding author: Carolina Bastidas, Tel/Fax 58-212-9063415
}

Received 15-VII-2011. C Corrected 16-XII-2011. Accepted 20-XII-2011.

\begin{abstract}
Thermal anomalies have become more severe, frequent and well-documented across the Caribbean for the past 30 years. This increase in temperature has caused coral bleaching resulting in reef decline. At Los Roques National Park, Venezuela, temperature has been monitored at four reef sites. In mid-September 2010, seawater temperature reached $30.85^{\circ} \mathrm{C}$ at $5 \mathrm{~m}$ depth in Los Roques, an archipelago only slightly affected by previous bleaching events. For example, bleaching in Los Roques in 2005 was mild compared to the rest of the Caribbean and to the results in this study. In 2010 , seawater temperatures remained above $29.0^{\circ} \mathrm{C}$ from midAugust until the first week of November, resulting in +16 Degree Heating Weeks by that time. Our annual survey of four reef sites indicated that $72 \%$ of 563 scleractinian colonies were partial or totally bleached (white) or pale (discolored) in October 2010. In February 2011, there were still 46\% of coral colonies affected; but most of them were pale and only $2 \%$ were bleached. By February, coral cover had declined 4 to $30 \%$ per transect, with a mean of $14.3 \%$. Thus, mean coral cover dropped significantly from 45 to $31 \%$ cover (a $34 \%$ reduction). In addition to bleaching, corals showed a high prevalence (up to 16\%) of black band disease in October 2010 and of white plague (11\%) in February 2011. As a consequence, coral mortality is expected to be larger than reported here. Reef surveys since 2002 and personal observations for more than 20 years indicated that this bleaching event and its consequences in Los Roques have no precedent. Our results suggest that reef sites with no previous record of significant deterioration are more likely to become affected by thermal anomalies. However, this archipelago is relatively unaffected by local anthropogenic disturbance and has a high coral recruitment, which may contribute to its recovery. Rev. Biol. Trop. 60 (Suppl. 1): 29-37. Epub 2012 March 01.
\end{abstract}

Key words: coral bleaching, mortality, loss of coral cover, Caribbean, coral reefs.

Coral reefs are tropical ecosystems with high productivity and therefore they provide a myriad of ecological goods and services to human societies, particularly in developing countries (Moberg \& Folke 1999). Coral reefs world-wide have shown signs of deterioration, mainly reported by the loss of coral cover. Hurricanes, bleaching, coral diseases, thermal anomalies and overfishing are among the factors that have been associated with coral reef deterioration (e.g. Bellwood et al. 2004, Rogers 2009). In the Caribbean this phenomenon has been particularly evident, as extensive reductions of coral cover and the concomitant loss of architectural complexity have occurred (Gardner et al. 2003, Weil et al. 2006, Alvarez-Filip et al. 2009).

Mass bleaching events (MBE, events that reduce the density of Symbiodinium in its hosts over a large geographic area) have increased 
in frequency and intensity (e.g. McWilliams et al. 2005); and it appears that they act synergistically with other detrimental factors to produce negative consequences for coral reef organisms, populations and communities (reviewed in Brown 1997). Thus, MBE have been reported across the Caribbean as a factor that reduces coral cover (e.g. Cortés 2003, Gardner et al. 2003). However, the effects and consequences of a particular bleaching event may vary between localities depending on oceanographic processes which is partly determined by reef morphology and topography; population size structure and species composition of coral communities (Brandt 2009). In 2005, prolonged thermal anomalies and its associated MBE occurred on a regional scale (e.g. Donner et al. 2007, Wilkinson \& Souter 2008, Brandt \& McManus 2009), but the largest coral cover losses related to this $\mathrm{MBE}$ were detected in the eastern Caribbean, where also epizootic events came after a prolonged bleaching period (Miller et al. 2006, Muller et al. 2008). In contrast, this bleaching event had mild effects in the southern Caribbean (Croquer \& Weil 2009); particularly, in Venezuela (Rodríguez et al. 2010).

In 2010, another mass bleaching event was recorded worldwide (Normile 2010), although apparently not as severe as in 2005 for the Caribbean. However, coral reefs at Los Roques National Park (LRNP) were severely affected in 2010. Los Roques is a marine protected area characterized by healthy coral reef ecosystems compared to other sites in the Caribbean (Villamizar et al. 2003, Croquer et al. 2010; but see Croquer et al. 2005). The relatively good conditions of coral reefs ecosystems at LRNP (e.g. Schweizer et al. 2005) might be explained by low anthropogenic impacts, absence of runoff; and perhaps by the combination of low hurricane activity, low frequency of bleaching events, and thermal anomalies which seldom exceed few weeks over this geographic area. In this paper we provide the first evidence of a mass bleaching event producing significant impacts on coral reefs at Los Roques National Park.

\section{MATERIAL AND METHODS}

Study site: LRNP is located about $150 \mathrm{~km}$ north of the Venezuelan coast. This marine protected area encompasses $2211.4 \mathrm{~km}^{2}$ of tropical marine ecosystems including mangroves, seagrass beds, soft-bottom communities, sandy and rocky shores and coral reefs. Reef development in Los Roques is extensive showing high diversity and live cover of scleractinian corals compared with other reef areas in Venezuela (Ramírez-Villarroel 2001) and other areas of the Caribbean (Rodríguez-Ramírez et al. 2008). Coral reefs at LRNP also differ within the region because of the presence of recovering populations of the threatened species Acropora palmata (Zubillaga et al. 2005) and A. cervicornis.

Seawater Temperatures: seawater temperatures were monitored with four $\mathrm{HOBO}$ data loggers (Pro-V2), at the four reef sites of the archipelago every 12 minutes. The loggers were fixed to the bottom near the coral, at an average depth of $5 \mathrm{~m}$ and the data shown here were from the 3rd of March 2010 to the 3rd of February 2011. The Degree Heating Weeks index (DHW) was calculated according to Liu et al. (2006). The estimation of monthly mean temperatures was done with a time series from May 2003 till July 2011 obtained from the MODIS-SCAR sensor (data obtained from http://cariaco.ws/).

Surveys of coral bleaching: In order to assess the magnitude of the $2010 \mathrm{MBE}$ and its effects on coral reefs in LRNP, the proportion of bleached or paled colonies as well as the live coral cover was determined along ten, 10-m long, permanent transects located at each reef site, covering a depth interval of 5 to $15 \mathrm{~m}$. This was carried out in October 2010, about one month after the onset of bleaching, and then again five months after the initial survey, in February 2011. During the initial survey, four reef sites (i.e. reefs located in the slope of different cays) were sampled: two located at the south-western edge of LRNP (Dos 
Mosquises and Cayo de Agua) and two located in the north-east (Madrizquí and Rabusquí). The maximum distance among reef sites was $36 \mathrm{~km}$, and their location and other characteristics have been described (Zubillaga et al. 2008, Croquer et al. 2010). Coral cover was estimated from chain transects (CARICOMP 2001), and the condition of coral colonies intercepted were also recorded (coloration, diseased, surface of partial mortality). In February of 2011, two sites were resurveyed (Cayo de Agua and Dos Mosquises Sur) to ascertain the effect of the bleaching event, six months after its onset. Therefore, comparisons between October 2010 and February 2011 were made only for these two sites, whereas results that pertain only to October 2010 were obtained from the observations at the four sites.

Statistical analysis: Null hypothesis of no temporal changes in live coral cover was compared with a repeated measures analysis of variances after checking ANOVA assumptions (i.e., normality and homogeneity of variances). Also a regression analysis was done to test whether the loss of live coral cover in each transect by February 2011 was linearly correlated with the proportion of colonies bleached in October 2010.

\section{RESULTS}

Seawater Temperature and Degree Heating Weeks: During 2010, the maximum temperature of $30.85{ }^{\circ} \mathrm{C}$ at $5 \mathrm{~m}$ depth was reached between the 17 and 19 of September at all four reef sites. At that depth, the seawater temperatures remained above $29.0^{\circ} \mathrm{C}$ from mid-August until the first week of November 2010 (Fig. 1A). By that time, Degree Heating Weeks (DWH) reached a maximum value of $16{ }^{\circ} \mathrm{C}$-weeks in the superficial waters of the archipelago (Fig. 1B, from NOAA) and $13{ }^{\circ} \mathrm{C}$-weeks in waters at $5 \mathrm{~m}$ (data from in situ loggers).

Percentage of bleached and diseased coral colonies: In October 2010, $72 \%$ of the 563 scleractinian colonies were bleached or pale. In February 2011, there were still $46 \%$ of coral colonies affected; but the recovery of zooxanthellae density was in place, as most of them were pale, and only $2 \%$ were bleached (Fig. 2).

The high prevalence of Black Band Disease (BBD) had no precedent since the beginning of our surveys in 2002. In fact, BBD has been only detected once before, in 2007, when it reached $1 \%$ in Dos Mosquises (DMS). In contrast, the prevalence of $\mathrm{BBD}$ was $6 \%$ in DMS and 16\% in Cayo de Agua (AGU) in October 2010. By February 2011, we did not observe any sign of BBD in these localities.

In 2010, the prevalence of White Plague (WP, with no differentiation made between type I and II) was also high compared to previous years. Contrasting with the drop in prevalence of BBD, the prevalence of WP was higher in February $2011(10-11 \%)$ than in October $2010(4-8 \%)$.

Analysis of the cover change: By October 2010, mean coral cover was $42.5 \% \pm 3.97( \pm$ standard error) in AGU and $47.4 \% \pm 3.41$ in DMS. By February 2011, it was $32.2 \% \pm 4.60$ and $29.1 \pm 3.44$, respectively. Thus, the coral cover dropped similarly between sites (repeated measures ANOVA Time*Reef p>0.05; Fig. 3) and significantly from a mean of 44.9 to $30.6 \%$ (Time $\mathrm{p}<0.05$ ), with a concomitant loss of $17 \%$ in the number of colonies.

Although there could be other causes for the rapid loss of coral cover (including the onset of diseases), a great proportion is certainly attributable to the bleaching event of 2010 . This assumption is based on the relatively short time period elapsed between the high seawater temperature anomaly and both surveys. Also, the proportion of bleached or pale colonies explained about $22 \%$ of the variability obtained in the net loss of coral cover in each transect $\left(\mathrm{r}^{2}\right.$ $=0.2165$ for the regression shown in Fig. 4).

\section{DISCUSSION}

Considering the combined global land and ocean surface temperature, the year 2010 tied with 2005 as the warmest on record (NOAA 2010). Also, both are known as years were mass bleaching events (MBE) have occurred 


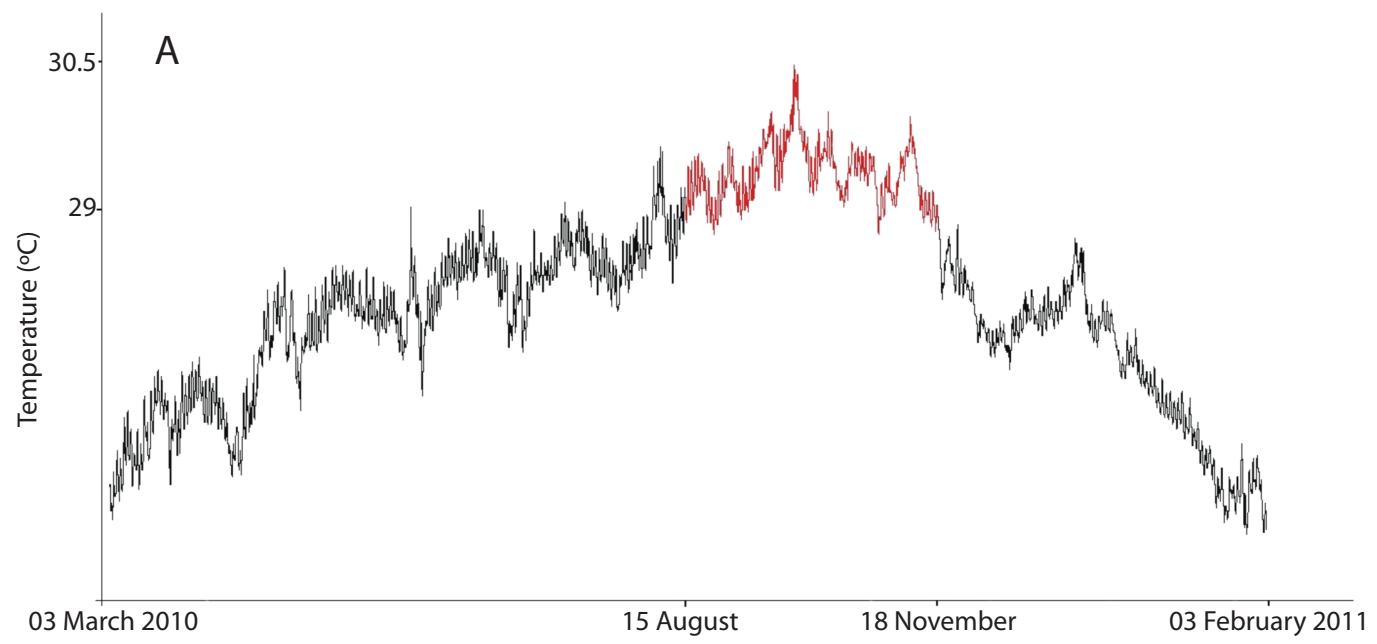

B NOAA/NESDIS Degree Heating Weeks for las 12 weeks - 11-1-2010

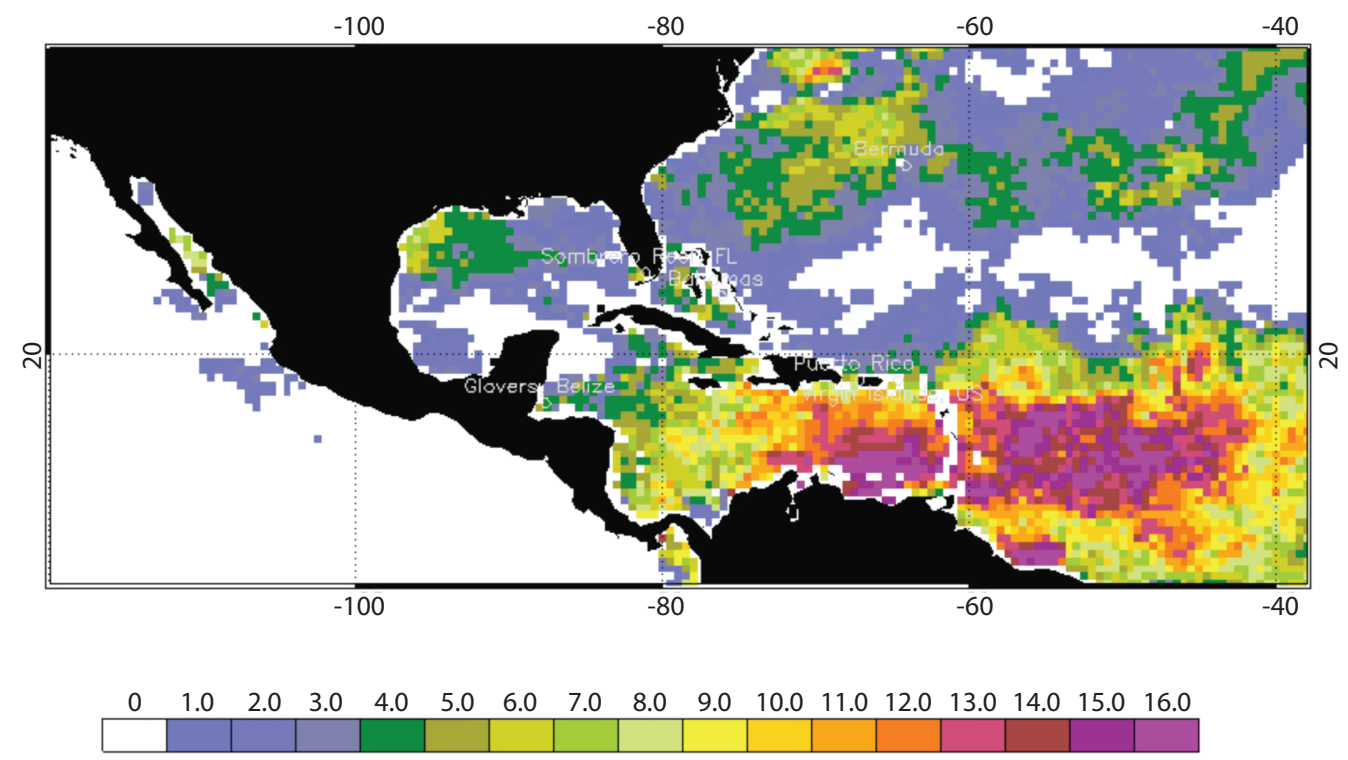

Fig. 1. A) Water temperature in ${ }^{\circ} \mathrm{C}$ at $5 \mathrm{~m}$ depth obtained in situ by a HOBO logger. Four reef sites were measured but only the data for Rabusquí is shown as it was very similar among sites. B) Degrees Heating Weeks (DHW) for the Caribbean region by November 1, 2010 (obtained from the NOAA, http://www.osdpd.noaa.gov/ml/ocean/cb/dhw_2010.html).

across the Caribbean. However, the intensity of the bleaching event and its consequences in Los Roques, Venezuela, were markedly different between these years. The bleaching event observed in October 2010 in Los Roques, and the consequences recorded up to February 2011, had no precedent since we started our surveys in 2002 and have no match with our observations for more than 20 years in Venezuelan reefs. Thus, these coral reefs fall within 


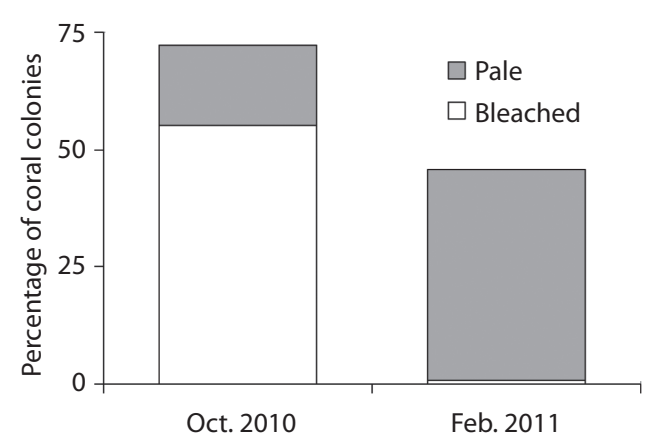

Fig. 2. Percentage of coral colonies that were bleached or pale in the sites surveyed in October $2010(\mathrm{~N}=563$; four reef sites) and in February 2011 ( $N=208$; two reef sites) in Los Roques, Venezuela.

the expectations of a higher incidence and/or frequency of massive event of bleaching as temperatures rise above coral bleaching thresholds (Hoegh-Guldberg 1999).

Previous bleaching events observed in Venezuelan coral reefs have been mild compared with those that occurred during the same periods in other Caribbean localities (e.g. Lang et al. 1992, Eakin et al. 2010). In Los Roques, in particular, less than $4 \%$ of coral colonies were bleached in August and September 2005 (Rodríguez et al. 2010), and $<10 \%$ across the archipelago at the peak of the event in November 2005 (Villamizar et al. 2008). In contrast, the $2005 \mathrm{MBE}$ was severe across the Caribbean, particularly in the eastern reefs, where percentage of bleached corals reached up to $80 \%$ (Ballantine et al. 2008, Oxenford et al. 2008, Brandt \& McManus 2009, Croquer \& Weil 2009, Miller et al. 2009, Eakin et al. 2010). A series of climatic and oceanic factors contribute to the variability in the thermal stress across the region (e.g. hurricanes, irradiance, water flow), which in turn results in spatial and temporal variations of the bleaching intensity (e.g. Jokiel \& Brown 2004).

The distribution of heat in the superficial water masses along the Venezuelan coast was completely different between 2005 and 2010 (Fig. 1A in Eakin et al. 2010 versus Fig. $1 \mathrm{~B}$ in this study) and this can be considered a factor contributing to the differences in bleaching intensity observed between 2005 and
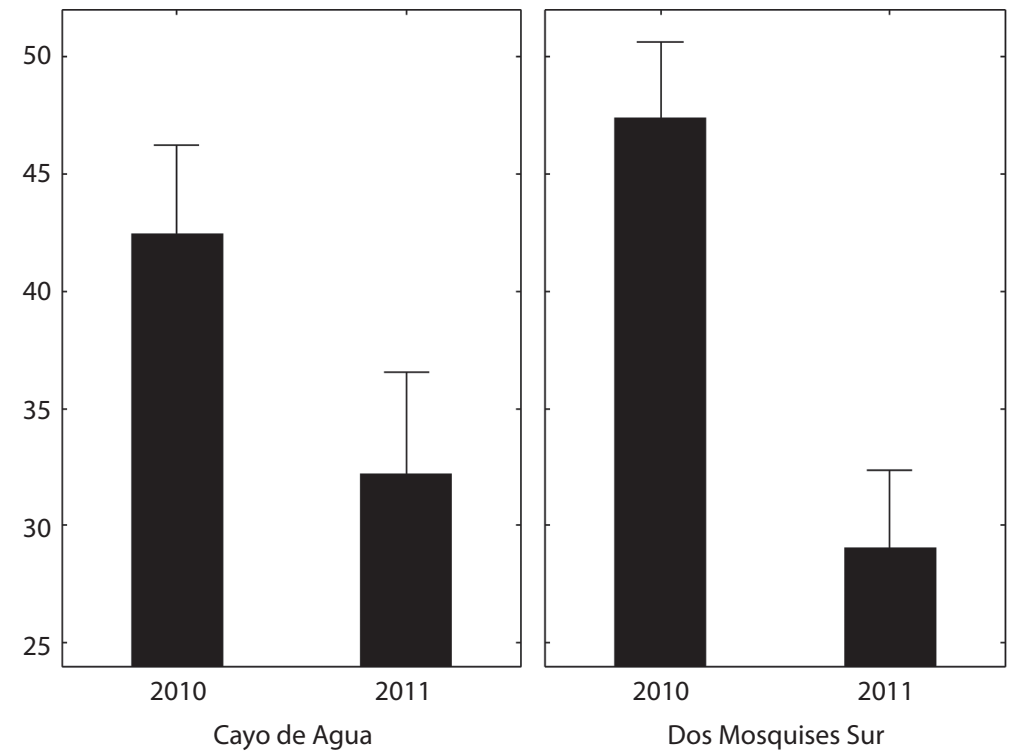

Fig. 3. Hard coral cover (\%) measured in October 2010 and in February 2011 at two reef sites (Cayo de Agua and Dos Mosquises); Los Roques, Venezuela. 


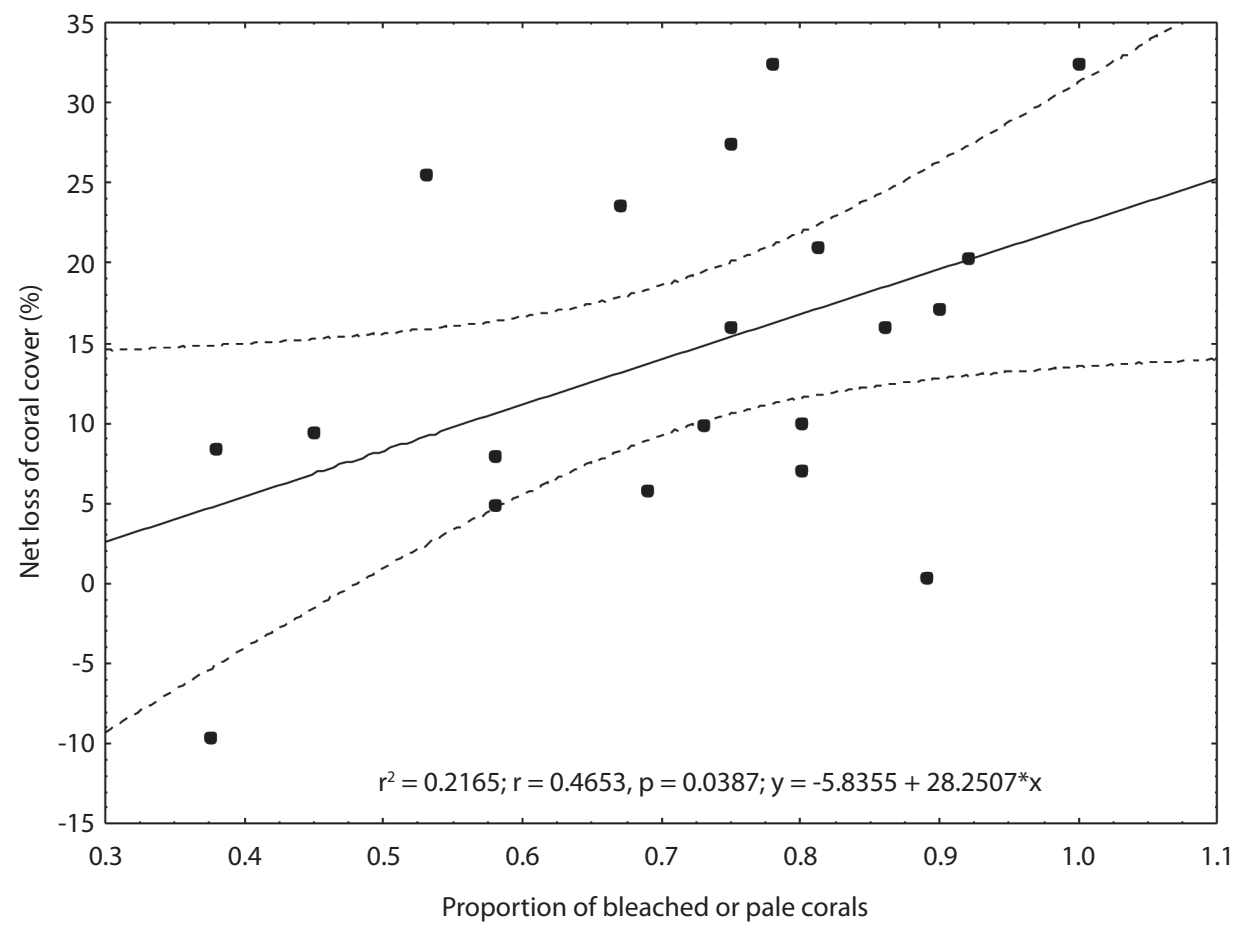

Fig. 4. Relationship between the net coral loss (\%) that occurred between October 2010 and February 2011, and the proportion of colonies that were bleached or pale by October 2010 at two reef sites in Los Roques, Venezuela.

2010. It is well known that bleaching severity is determined by a combination of intensity and duration of thermal stress and irradiance conditions (Glynn \& D'Croz 1990, Lesser \& Farrell 2004). In situ measurements indicated that maximum temperatures in the archipelago (excluding the internal lagoon) were about $1{ }^{\circ} \mathrm{C}$ higher in 2010 than in 2005 for the same period $\left(29.92{ }^{\circ} \mathrm{C}\right.$ in 2005 vs. $30.85^{\circ} \mathrm{C}$ in 2010$)$. Concomitantly, Degree Heating Weeks (DHW) calculated from in situ loggers did not exceed the value of $5{ }^{\circ} \mathrm{C}$-weeks in 2005 (Villamizar et al. 2008) for the reefs surveyed in this study, whereas it reached $13{ }^{\circ} \mathrm{C}$-weeks in 2010 . It has been generalized that values of over $4^{\circ} \mathrm{C}$-weeks cause significant bleaching, and values over $8^{\circ} \mathrm{C}$-weeks cause widespread bleaching and some mortality (Liu et al. 2006), which was also the case in this study.

Another example of the variability in bleaching intensity is illustrated by the differences found between the 2005 and 2010 MBE in Venezuela. In 2005, bleaching intensity was higher in coastal rather than oceanic reefs $(16 \%$ vs. $<4$ of bleached corals, Rodríguez et al. 2010). The opposite trend was found in 2010, when intensity seemed higher for the oceanic reefs of Los Roques compared to coastal reefs of Morrocoy (personal observations). These results contrasted with other studies that have consistently found more severe MBE in inshore waters compared to outer reefs (e.g. Berkelmans et al. 2004).

Coral cover was severely reduced (by $36 \%$ ) at our study sites in Los Roques after the 2010 bleaching event, which was similar to the $40 \%$ mortality observed in 2005 across the Caribbean (Eakin et al. 2010). However, we suspect that the long- term consequences could be worse in Los Roques, because during our last survey (February 2011): a) the bleaching was still ongoing as $46 \%$ of colonies remained 
pale, despite a drop in seawater temperature; and b) there was a high prevalence of white plague $(\sim 10 \%)$ by that time. Previous studies indicate that after a MBE, the mortality of corals can span for about two years (e.g. Eakin et al. 2010), as well as its detrimental consequences on coral reproduction (e.g. Szmant \& Gassman 1990). Also, the onset of diseases associated to the MBE, particularly black band disease, white plague and yellow band disease, can contribute further to the loss of coral cover (e.g. Brandt \& McManus 2009, Miller et al. 2009, Weil et al. 2009).

The loss of coral cover induced by the 2010 MBE in Los Roques has no precedent at least in 20 years. Although we expect that MBEinduced coral mortality to continue for several months after our last survey, a rapid recovery in Los Roques could be possible because a relatively high coral cover $(\sim 30 \%)$ is still present in many reefs of the archipelago, there is relative low anthropogenic impact (e.g. a permanent population of $\sim 2,000$ inhabitants), and high coral recruitment rates have been found (Humanes 2009). Venezuelan coastal reefs, that lack these conditions, have shown very slow recovery after massive mortality events (Bastidas et al. 2006). Unfortunately, the positive expectations for the recovery of reefs in Los Roques depend on other large scale factors that are difficult to foresee, such as the distribution of thermal anomalies across the Caribbean.

\section{ACKNOWLEDGMENTS}

We would like to thank Mitsui Ltd for funding a project that includes the environmental monitoring of Los Roques in 2009 and 2010; the Instituto Nacional de Parques (INPARQUES) for issuing the permits to work in the park; and the useful comments of two anonymous reviewers that greatly helped to improve the manuscript.

\section{RESUMEN}

Durante las últimas décadas las anomalías térmicas han sido más frecuentes y severas en el Caribe, quedando pocos arrecifes exentos de eventos masivos de blanqueamiento (EMB). En el Parque Nacional Los Roques, Venezuela, un archipiélago poco afectado previamente por EMB, la temperatura del agua a $5 \mathrm{~m}$ de profundidad alcanzó $30,85^{\circ} \mathrm{C}$ en septiembre 2010 , y fue $>29,0^{\circ} \mathrm{C}$ entre mediados de agosto y la primera semana de noviembre en cuatro arrecifes. El $72 \%$ de 563 colonias de escleractinios estaban blanqueadas o pálidas para octubre de 2010, mientras que para febrero 2011, el $46 \%$ de las colonias aún estaban afectadas. Para febrero 2011, la cobertura béntica coralina promedio disminuyó de 45 a $31 \%$. Además, los arrecifes mostraron una alta prevalencia (de hasta 16\%) de enfermedad de banda negra en Octubre 2010, y de plaga blanca (11\%) en Febrero 2011. Como consecuencia, es probable que la mortalidad coralina resulte mayor a la reportada acá. Sin embargo, Los Roques es poco afectado por perturbaciones antropogénicas y cuenta con un alto reclutamiento de corales, lo cual podría contribuir a su recuperación.

Palabras clave: blanqueamiento coralino, mortalidad, pérdida de cobertura de coral, Caribe, arrecife coralino.

\section{REFERENCES}

Alvarez-Filip, L., N.K. Dulvy, J.A. Gill1, I.M. Côté \& A.R. Watkinson. 2009. Flattening of Caribbean coral reefs: region-wide declines in architectural complexity. Proc. Roy. Soc. B 276: 3019-3025.

Bastidas, C., A. Croquer \& D. Bone. 2006. Shifts of dominance species after a mass mortality on a Caribbean Reef. Proc. 10th Int. Coral Reef Symp., Okinawa: 989-993.

Ballantine, D.L., R.S. Appeldoorn, P. Yoshioka, E. Weil, R. Armstrong, J.R. Garcia, E. Otero, F. Pagan, C. Sherman, E. Hernandez-Delgado, A. Bruckner \& C. Lilyestrom. 2008. Chapter 9. Biology and ecology of Puerto Rican coral reefs, pp 375-406. In: B. Riegl \& R.E. Dodge (eds.). Coral Reefs of the USA. Springer, Dortrecht.

Bellwood, D.R., T.P. Hughes, C. Folke \& M. Nystrom. 2004. Confronting the coral reef crisis. Nature 429 : 827-833.

Berkelmans, R., G. De'ath, S. Kininmonth \& W.J. Skirving. 2004. A comparison of the 1998 and 2002 coral bleaching events on the Great Barrier Reef: spatial 
correlation, patterns and predictions. Coral Reefs 23: 74-83.

Brandt, M.E. 2009. The effect of species and colony size on the bleaching response of reef-building corals in the Florida Keys during the 2005 mass bleaching event. Coral Reefs 28: 911-924.

Brandt, M.E. \& J.W. McManus. 2009. Disease incidence is related to bleaching extent in reef-building corals. Ecology 90: 2859-2867.

Brown, B.E. 1997. Coral bleaching: causes and consequences. Coral Reefs 16 (Suppl): S129-S138.

CARICOMP. 2001. Methods Manual Level 1 and 2: Manual of Methods for Mapping and Monitoring of Physical and Biological Parameters in the Coastal Zone of the Caribbean. Kingston.

Cortés, J. 2003. Latin American Coral Reefs. Elsevier, Amsterdam, The Netherlands.

Croquer, A., E. Weil \& A.L. Zubillaga. 2005. Effects of white plague disease-II outbreak on the coral community structure of Madrizquí Key, Los Roques National Park, Venezuela. Carib. J. Sci. 41: 815-823

Croquer, A., D. Debrot, E. Klein, M. Kurten, S. Rodríguez \& C. Bastidas. 2010. What two years of monitoring tell us about Venezuelan coral reefs? The southern Tropical America node of the Global coral reef monitoring network (STA-GCRMN). Rev Biol. Trop. 58 (Suppl. 1): 51-65

Croquer, A. \& E. Weil. 2009. Changes in disease prevalence after the 2005 bleaching event. Dis. Aquat. Org. 87: $33-43$.

Donner S.D., T.R. Knutson \& M. Oppenheimer. 2007. Model-based assessment of the role of human-induced climate change in the 2005 Caribbean coral bleaching event. Proc Natl. Acad. Sci. USA 104: 5483-5488

Eakin, M., J.A. Morgan, S.F. Heron, T.B. Smith, G. Liu, L. Alvarez-Filip, B. Baca, E. Bartels, C. Bastidas, et al. 2010. Caribbean corals in crisis: record thermal stress, bleaching, and mortality in 2005. PLoS ONE 5(11): e13696

Gardner, T., I.M. Côté, J.A. Gill, A. Grant \& A.R. Watkinson. 2003. Long-term region-wide declines in Caribbean corals. Science 301: 958-960.

Glynn P.W. \& L. D’Croz. 1990. Experimental evidence for high temperature stress as the cause of El Niño mortality. Coral Reefs 8: 181-191
Hoegh-Guldberg, O. 1999. Climate change, coral bleaching and the future of the world's coral reefs. Mar. Freshwater Res. 50: 839-866.

Humanes, A. 2009. Asentamiento y sobrevivencia de corales pétreos en el Parque Nacional Archipiélago Los Roques. Tesis de Maestría en la Universidad Simón Bolívar, Caracas.

Jokiel, P.L. \& E.K. Brown. 2004. Global warming, regional trends and inshore environmental conditions influence coral bleaching in Hawaii. Glob. Change Biol. 10: $1627-1641$

Lang, J., H.R. Lasker, E.H. Gladfelter, P. Hallock, W.C. Jaap, F.J. Losada \& R.G. Muller. 1992. Spatial and temporal variability during periods of "recovery" after mass bleaching on Western Atlantic coral reefs. Amer. Zool. 32: 696-706.

Lesser, M.P. \& J.H. Farrell. 2004. Exposure to solar radiation increases damage to both host tissues and algal symbionts of corals Turing thermal stress. Coral Reefs 23: 367-377.

Liu, G., A.E. Strong, W.J. Skirving \& L.F. Arzayus. 2006. Overview of NOAA Coral Reef Watch Program's near-real-time satellite global coral bleaching monitoring activities. Proc. 10th Int. Coral Reef Symp., Okinawa: 1783-1793.

McWilliams, J.P., I.M. Côté, J.A. Gill, W.J. Sutherland \& A.R. Watkinson. 2005. Accelerating impacts of temperature-induced coral bleaching in the Caribbean. Ecology 86: 2055-2060.

Miller, J., R. Waara, E. Muller \& C. Rogers. 2006. Coral bleaching and disease combine to cause extensive mortality on reefs in US Virgin Islands. Coral Reefs 25: 418-418

Miller, J., E. Muller, C. Rogers, R. Waara, A. Atkinson, K.R.T. Whelan, M. Patterson \& B. Witcher. 2009. Coral disease following massive bleaching in 2005 causes $60 \%$ decline in coral cover on reefs in the US Virgin Islands. Coral Reefs 28: 925-937.

Muller, E.M., C.S. Rogers, A.S. Spitzack \& R. van Woesik. 2008. Bleaching increases likelihood of disease on Acropora palmata (Lamarck) in Hawksnest Bay, St. John, U.S. Virgin Islands. Coral Reefs 27: 191-195.

Moberg, F. \& C. Folke. 1999. Ecological goods and services of coral reef ecosystems. Ecol. Econ. 29: 215-233.

NOAA. 2010. National Climatic Data Center, State of the Climate: National Overview for Annual 2010 , 
published online December 2010, retrieved on July 14, 2011 from http://www.ncdc.noaa.gov/ sotc/2010/13.

Normile, D. 2010. Hard summer for corals kindles fears for survival of reefs. Science 329: 1001.

Oxenford, H.A., R. Roach, A. Brathwaite, L. Nurse, R. Goodridge, F. Hinds, K. Baldwin \& C. Finney. 2008. Quantitative observations of a major coral bleaching event in Barbados, Southeastern Caribbean. Climat. Chan. 87: 435-449

Ramírez-Villarroel, P. 2001. Corales de Venezuela. Gráficas Internacional, Porlamar. 254 p.

Rogers, C. 2009. Coral bleaching and disease should not be underestimated as causes of Caribbean coral reef decline. Proc. Royal Soc. B 276: 197-198.

Rodríguez, S., A. Croquer, D. Bone \& C. Bastidas. 2010. Severity of the 1998 and 2005 bleaching events in Venezuela, southern Caribbean. Rev. Biol. Trop. 58 (Suppl. 3): 189-196.

Rodríguez-Ramírez, A., C. Bastidas, S. Rodríguez, Z. Leão, R. Kikuchi, M. Oliveira, D. Gil, J. GarzónFerreira, M.C. Reyes-Nivia, R. Navas-Camacho et al. 2008. The effects of coral bleaching in Southern Tropical America: Brazil, Colombia, and Venezuela: p. 105-114. In C. Wilkinson \& D. Souter (Eds). Status of Caribbean Coral Reefs After Bleaching and Hurricanes in 2005. Global Coral Reef Monitoring Network, and Reef and Rainforest Research Centre, Townsville, Australia.

Schweizer, D., R.A. Armstrong \& J. Posada. 2005. Remote sensing characterization of benthic habitats and submerged vegetation biomass in Los Roques Archipelago National Park, Venezuela. Int. J. Rem. Sen. 26: 2657-2667.
Szmant, A.M. \& N.J. Gassman. 1990. The effects of prolonged "bleaching" on the tissue biomass and reproduction of the reef coral Montastrea annularis. Coral Reefs 8: 217- 224.

Villamizar, E., J.M. Posada \& S. Gómez. 2003. Rapid assessment of coral reefs in the Archipiélago de Los Roques National Park, Venezuela (Part I: stony corals and algae). In: J.C. Lang (ed.). Status of Coral Reefs in the Western Atlantic: Results of Initial Surveys, Atlantic and Gulf Rapid Reef Assessment. Atoll Res. Bull. 496: 512-529.

Villamizar, E., H. Camisotti, B. Rodríguez, J. Pérez \& M. Romero. 2008. Impacts of the 2005 Caribbean bleaching event at Archipiélago de Los Roques National Park, Venezuela. Rev. Biol. Trop. 56 (Suppl. 1): 255- 270.

Weil, E., G. Smith \& D.L. Gil-Agudelo. 2006. Status and progress in coral reef disease research. Dis. Aquat. Org. 69: 1-7.

Weil, E., A. Croquer, I. Urreiztieta \& E. Irizarry. 2009. Temporal variability and impact of coral diseases and bleaching in La Parguera Puerto Rico, from 20032007. Carib. J. Sci. 45: 1-26.

Wilkinson, C.R. \& D. Souter (eds.). 2008. Status of Caribbean Coral Reefs After Bleaching and Hurricanes in 2005. Global Coral Reef Monitoring Network, and Reef and Rainforest Research Centre, Townsville, Australia

Zubillaga, A.L., C. Bastidas \& A. Croquer. 2005. High densities of the coral Acropora palmata in Cayo de Agua, Archipelago Los Roques National Park, Venezuela. Coral Reefs 24: 86.

Zubillaga, A.L., L.M. Marquez, A. Croquer \& C. Bastidas. 2008. Ecological and molecular approaches indicate recovery of the endangered coral species Acropora palmata. Coral Reefs 27:63-72. 
